\title{
Modulation of antioxidant defense system by polyherbal extract mixture which ameliorated the pathophysiological alterations in streptozotocin induced diabetic rats
}

\author{
Shaul Ahmed R., Urvesh D. Patel, Dixita H. Bhadarka, Harshad B. Patel and Chirag M. Modi \\ Department of Pharmacology and Toxicology, College of Veterinary Science and Animal Husbandry \\ Junagadh Agricultural University, Junagadh-362 001, Gujarat, India
}

Received September 17, 2018: Revised November 7, 2018: Accepted November 11, 2018: Published online December 30, 2018

\begin{abstract}
Diabetes mellitus is described as a metabolic disorder of multiple etiology, characterized by chronic hyperglycemia with disturbances of carbohydrate, lipid and protein metabolism, resulting from defects in insulin secretion, insulin action, or both. Looking into the pharmacological properties of different plant varieties like Allium cepa, Trigonella foenum-graecum, Tinospora cordifolia, Gymnema sylvestre, Syzygium cumini and Momordica charantia, the study was carried out to evaluate the effect of polyherbal extract mixture (PHEM) on blood glucose level, lipid profile and other pathophysiological alterations in streptozotocin induced diabetic rats. Thirty Sprague-Dawley rats were randomly divided based on body weight in five groups $(\mathrm{C} 1, \mathrm{C} 2, \mathrm{C} 3, \mathrm{~T} 1$ and $\mathrm{T} 2)$. Rats of four groups (C2, C3, T1 and T2) were injected with streptozotocin to induce diabetes. Rats of group C1, C2, and C3 were kept as normal, diabetic and standard control, respectively. Rats of group C3 were administrated with glibenclamide $(5 \mathrm{mg} / \mathrm{kg}$, PO for 28 days). Rats of group T1 and T2 were treated with PHEM at 100 and $200 \mathrm{mg} / \mathrm{kg}$, respectively orally for 28 days. Administration of PHEM significantly reduced the blood glucose level in T1 and T2 experimental groups after 28 days of treatment. In lipid profile, mean values of total cholesterol, triglyceride, HDL-cholesterol and LDL-cholesterol in rats treated with PHEM were found comparable to those of control rats. Altered biochemical enzymes like AST, ALT, ALP and bilirubin were normalized by administration of PHEM in diabetic rats. Antioxidant enzymes which got altered in diabetic rats were also normalized in rats under the treatment of PHEM. In conclusion, administration of polyherbal extract mixture at the dose rate of $200 \mathrm{mg} / \mathrm{kg}$, PO for 28 days have shown ameliorating effect against STZ induced alterations in glucose level, lipid profile, oxidative status and other pathological changes in rats.
\end{abstract}

Key words: Glucose level, blood parameters, histopathological evaluation, polyherbal extract mixture, diabetic rat model

\section{Introduction}

Diabetes mellitus is a chronic heterogeneous metabolic disorder characterized by loss of glucose homeostasis which results from defect in insulin secretion or an insulin action or sometimes both (Jha et al., 2018). It is a major endocrine disorder, fast gaining the status of a potential epidemic in India (Kumar et al., 2006). The metabolic abnormalities that characterize diabetes, such as hyperglycemia, increased free fatty acids and an insulin resistance can provoke molecular mechanisms that contribute to vascular dysfunction (Creager and Lusher, 2003). Diabetes is a major healthcare problem, since it increases the risk of heart disease, stroke and microvascular complications such as blindness, renal failure and peripheral neuropathy (Frances and Patrik, 2012). The phenomenon of oxidative stress resulting from the imbalance of a

\footnotetext{
Author for correspondence: Dr. Urvesh D. Patel

Assosiate Professor, Department of Pharmacology and Toxicology, College of Veterinary Science and Animal Husbandry, Junagadh Agricultural University, Junagadh-362 001, Gujarat, India E-mail: urvesh1981@yahoo.com Tel.: + 91-9725003818
}

Copyright @ 2018 Ukaaz Publications. All rights reserved.

Email: ukaaz@yahoo.com; Website: www.ukaazpublications.com critical balance of pro-oxidants and antioxidants in the organism has scientifically been established as a vital player in the pathology of chronic ailments (Gul et al., 2016; Rajeshwari et al., 2013, Tayyab and Lal, 2016). Production of reactive oxygen species (ROS) in oxidative stress is proposed as the important cause of progression of $\beta$-cell dysfunction, insulin resistance, impaired glucose tolerance and type 2 diabetes mellitus (Wright et al., 2006).

In addition to insulin, oral hypoglycemic agents like sulphonylureas, thiozolidinediones, biguanides, D-phenylalanine derivatives, meglitinides and $\alpha$-glucosidase inhibitors are the conventional drugs used for the treatment of diabetes. However, use of these allopathic drugs for prolong period may cause side effects like hypoglycemia, nausea, vomition, hyponatremia, flatulence, gastrointestinal disturbance, headache, weight gain, lactic acidosis, pernicious anemia, dyspepsia, dizziness and joint pain. Hence, instead of allopathic drugs, herbal drugs are good option for management of diabetes which has no or lesser side effects (Kokar and Mantham, 1998).

It is estimated that around 30000 plants species are known to have importance and of which 15000 plants are known to have worldwide use as drugs (Manoharachary and Nagaraju, 2016). Many herbal 
plants have been evaluated so far for having antidiabetic effects and also used by people for prevention and treatment of diabetes in India and all over the world. Different formulations of herbal origin are also available in the market for the treatment of diabetes. Despite the availability of many marketed herbal antidiabetic products, the formulation having antidiabetic effect along with protective role against diabetic complication is needed. Gymnema sylvestre (Retz.) Schult., Allium cepa L., Momordica charantia L., Trigonella foenumgraecum L. (Ghorbani, 2013) Tinospora cordifolia (Willd.) Miers (Shaul et al., 2017) and Syzygium cumini L. Skeels (Nayak and Subrata De, 2013) have been individually reported to have role in diabetes. We hypothesized that the mixture of extracts of all these plants might produce good results in diabetes as well as such study with mixture containing all these adaptogens have not been evaluated for evaluation of antioxidant mediated protective role in diabetes. Thus, above all plants have been selected to prepare polyherbal extract mixture (PHEM) and used to evaluate its effect on blood glucose level, lipid profile with other blood parameters and histopathological changes in STZ-induced diabetic rodent model.

\section{Materials and Methods}

\subsection{Experimental animals}

The study was carried out on 30 male Sprague-Dawley rats of 6-8 weeks of age. Rats were procured from registered breeder. All experimental animals were maintained as per guidelines of the Committee for the Purpose of Control and Supervision of Experiments on Animals (CPCSEA). The experiment protocol was approved by the Institutional Animal Ethics Committee (IAEC) of Institute (Protocol No. JAU/JVC/IAEC/SA/16/2017).

\subsection{Animal husbandry}

The polypropylene cages with stainless steel top grill was used to house rats. The cages were changed at least thrice in a week. During entire study period, the animals were housed in the cool environmental temperature $\left(23^{\circ} \mathrm{C}\right.$ to $\left.26^{\circ} \mathrm{C}\right)$ with relative humidity ranged between 40 to $55 \%$. Twelve hour light-dark cycle was maintained in laboratory animal room. Rat pelleted feed (VRK biological system, India) containing $18 \%$ protein was provided ad libitum to animals throughout the study period.

\subsection{Plant materials and chemicals}

Plant materials (leaves of Gymnema sylvestre (Retz.) Schult.,peels of Allium cepa L., fruit of Momordica charantia L., stem of Tinospora cordifolia (Willd.) Miers and dried seeds of Trigonella foenum-graecum L. and Syzygium cumini (L.) Skeels were collected from nearby area of Junagadh and authenticated by Mr. Punit Bhatt, Pharmacognosist, Department of Veterinary Pharmacology and Toxicology, College of Veterinary Science and A.H., Junagadh Agricultural University, Junagadh, India. The specimens of above plants were submitted to the Department of Veterinary Pharmacology and Toxicology, College of Veterinary Science and A.H., Junagadh Agricultural University, Junagadh, Gujarat (Specimen No. JVC/VPT/SP/15/2017 to JVC/VPT/SP/20/2017). Each plant material was subjected to shade dry at room temperature and was finely powdered using electric grinder and stored in air tight glass containers for further use. Streptozotocin (STZ) and glibenclamide (GLB) with lot No. CMS1758 and BCBN1690V, respectively were procured from Sigma Aldrich. Standard kits
(Diatek Health Care Pvt. Ltd.) were used for analysis of serum biochemical parameters. Hydro-alcoholic (50:50) extract of each powder was prepared and mixed in equal proportion to prepare polyherbal extract mixture (PHEM).

\subsection{Induction of diabetes}

Citrate buffer previously adjusted to $\mathrm{pH} 4.5$ with $0.1 \mathrm{M}$ citric acid was used to dissolve streptozotocin (STZ). This solution was administered by single intra-peritoneal injection at a dose rate of 50 $\mathrm{mg} / \mathrm{kg}$ body weight to all animals except animals of group C1 (Normal control). Diabetes was confirmed after $48 \mathrm{~h}$ by measuring the level of blood glucose using glucometer (Alere GI, India). Rats with blood glucose level above $>150 \mathrm{mg} / \mathrm{dl}$ were considered as diabetic and were used in the experiment (Kotadiya et al., 2017ab; Kotadiya et al.,2018). All rats were randomly divided into different experimental groups based on their blood glucose level and body weight.

\subsection{Experimental design}

Completely Randomized Design (CRD) was employed with five different treatment groups having six rats in each treatment group. Rats of group C1, C2, and C3 were kept as normal, diabetic and standard control, respectively. Rats of group C3 were administrated with glibenclamide ( $5 \mathrm{mg} / \mathrm{kg}$, PO for 28 days). Rats of group T1 and T2 were treated with PHEM at 100 and $200 \mathrm{mg} / \mathrm{kg}$, respectively orally for 28 days.

\subsection{Physical examinations, body weight and feed consumption}

All rats during the entire study period were examined daily for any abnormal physical and behavioral changes. The body weight of individual rat was recorded daily. Feed offered to each group was accurately recorded daily in the morning and the residual feed given day before was also accounted. Based on these data, amount of feed consumed by rats of each group was calculated on daily basis.

\subsection{Blood glucose levels and oral glucose tolerance test (OGTT)}

Blood glucose level was estimated on day 0, 15, 22 and 29 of experiment, using glucometer (Alere GI, India). Oral glucose tolerance test (OGTT) was also carried out on day 15 of experimental period to check the status of diabetes. Glucose $(2 \mathrm{~g} / \mathrm{kg})$ was administered to overnight fasted animals of all groups. Control animals (Group 1) were administered with equal volume of water only. Blood samples were withdrawn from retro-orbital plexus of each animal after glucose administration at 0,30, 60, 90 and 120 min to know blood glucose level (Hepcy et al., 2012).

\subsection{Hematological evaluation}

Hematological parameters like hemoglobin (Hb), packed cell volume (PCV), total erythrocyte count (TEC), total leucocyte count, (TLC), mean corpuscular volume (MCV), mean corpuscular hemoglobin concentration (MCHC) and mean corpuscular hemoglobin $(\mathrm{MCH})$ were estimated by using automated hematology analyzer (Abacus Junior Vet 5, Diatron, Hungary) at Department of Veterinary Pathology, Junagadh Agricultural University, Junagadh, India.

\subsection{Biochemical parameters}

Biochemical parameters like blood glucose, total cholesterol (TC), HDL cholesterol, LDL cholesterol, triglyceride (TG), alanine aminotransferase (ALT), aspartate amino transferase (AST), alkaline 
phosphatase (ALP), blood urea nitrogen (BUN), creatinine (CRT), total protein (TP), albumin (ALB), globulin (GLB) and total bilirubin (TB) were estimated by using standard kits with fully automatic biochemistry analyzer (Diatek Health Care Pvt. Ltd.).

\subsection{Oxidative stress markers}

\subsubsection{Collection and preparation of samples}

All rats were humanely sacrificed on $29^{\text {th }}$ day of experiment and tissues of pancreas, liver and kidney were collected in phosphate buffer for evaluation of parameters of oxidative stress. Blood sample $(50 \mu 1)$ was mixed with $450 \mu 1$ of RBC lysis buffer (Sigma Aldrich, Lot no. RNBG 0536) and kept for 5 min for efficient erythrocyte lysis. The resultant blood lysate was used for evaluation of catalase and glutathione (GSH) antioxidant enzymes, whereas the direct serum sample was used for analysis of superoxide dismutase (SOD). Pancreas, liver and kidney samples $(100 \mathrm{mg})$ were collected from all rats and immediately stored in ice cold $0.1 \mathrm{M}(1 \mathrm{ml})$ phosphate buffer ( $\mathrm{PB}, \mathrm{pH}: 7.4)$ for evaluation of catalase and GSH, whereas pancreas, liver and kidney samples $(0.5 \mathrm{~g})$ were separately collected in Tris-EDTA buffer $(\mathrm{pH}: 8.2)$ for analysis of SOD. Protein estimation in pancreas, liver and kidney was carried out using the standard method (Bradford, 1976). These data were used to calculate catalase activity in liver and kidney tissues.

\subsubsection{SOD activity in serum sample}

Serum (Cu-Zn) SOD activity was determined by a simple and rapid method based on the ability of the enzyme to inhibit the autoxidation of pyrogallol (Marklund and Marklund, 1974). The autoxidation of pyrogallol was investigated in the presence of Tris-EDTA at $\mathrm{pH}$ range 7.9-10.6. The rate of autoxidation increases with increasing $\mathrm{pH}$. The autoxidation of pyrogallol in the presence of Tris-EDTA buffer at $\mathrm{pH}$ range $8.2-8.5$ is $50 \%$. For control reading: To $2.9 \mathrm{ml}$ of Tris-EDTA buffer, $0.1 \mathrm{ml}(20 \mathrm{mM})$ of pyrogallol solution was added, mixed and reading was taken at $420 \mathrm{~nm}$, exactly after $1 \mathrm{~min} 30 \mathrm{sec}$ and $3 \mathrm{~min} 30 \mathrm{sec}$. The absorbance (A) per two minutes difference was recorded, which shows rate of autoxidation of pyrogallol. For sample reading: To $2.8 \mathrm{ml}$ of Tris-EDTA buffer, $0.1 \mathrm{ml}$ of serum sample was added, mixed and started the reaction by adding $0.1 \mathrm{ml}$ of pyrogallol solution (as per control). It was read at $420 \mathrm{~nm}$ exactly after $1 \mathrm{~min} 30 \mathrm{sec}$ and $3 \mathrm{~min} 30 \mathrm{sec}$ and absorbance (B) per $2 \mathrm{~min}$ difference was recorded. Units of SOD/3 $\mathrm{ml}$ of assay mixture was calculated from $(\mathrm{A}-\mathrm{B}) \times \frac{100}{\mathrm{~A} \times 50}$.

Unit $\times 10=$ Units $/ \mathrm{ml}$ of sample solution. One unit of superoxide dismutase is described as the amount of enzyme required to cause $50 \%$ inhibition of pyrogallol auto oxidation per $3 \mathrm{ml}$ assay mixture.

\subsubsection{SOD activity in liver and kidney tissues}

Superoxide dismutase (SOD) activity in tissues was determined according to the method described previously (Marklund and Marklund, 1974). All tissue homogenates were prepared in TrisEDTA buffer centrifuged for $40 \mathrm{~min}$ at $10000 \mathrm{rpm}$ at $4{ }^{\circ} \mathrm{C}$; the supernatant was used for the enzyme assay. Tris-EDTA $(2900 \mu \mathrm{l})$ and $100 \mu$ pyrogallol $(2 \mathrm{mM})$ were taken in the cuvette and scanned for $3 \mathrm{~min}$ at $420 \mathrm{~nm}$ wavelength. Tris-EDTA buffer $(2890 \mu \mathrm{l}, \mathrm{pH}$ 8.2), $100 \mu \mathrm{l}$ pyrogallol and $10 \mu \mathrm{l}$ of tissue homogenate were taken and scanned for $3 \mathrm{~min}$ at the same wavelength. One unit of SOD activity is the amount of the enzyme that inhibits the rate of auto oxidation of pyrogallol by $50 \%$ and was expressed as units $/ \mathrm{mg}$ protein/min. The enzyme unit can be calculated by using the following equations:

$$
\% \text { of inhibition }=\frac{(\mathrm{A}-\mathrm{B}) \times 100}{\mathrm{~B}} .
$$

$$
\text { Enzyme unit }(\mathrm{U})=\frac{(\% \text { of inhibition }) \times}{50 \% \text { inhibition is similar to1 } \mathrm{U}}
$$

$50 \%$ inhibition is similar to $1 \mathrm{U}$.

\subsubsection{Catalase activity in blood}

Twenty $\mu 1$ of blood lysate was mixed with $1980 \mu 1$ PB $(0.1$ M PB, $\mathrm{pH} 7.5$ ) in a test tube. Then $1 \mathrm{ml}$ of $30 \mathrm{mM} \mathrm{H}_{2} \mathrm{O}_{2}$ was added to it and absorbance of reaction was taken at $240 \mathrm{~nm}$ in a spectrophotometer for $1 \mathrm{~min}$, against blank having mixture of PB and blood lysate only without $\mathrm{H}_{2} \mathrm{O}_{2}$. Unit activity of catalase was expressed in molar/min (Aebi et al., 1974).

\subsubsection{Catalase activity from tissue}

Tissue samples $(100 \mathrm{mg})$ of pancreas, liver and kidney were homogenized using $1 \mathrm{ml} \mathrm{PB}(0.1 \mathrm{M}, \mathrm{pH} 7.4)$ and centrifuged at $10,000 \mathrm{rpm}$ for $5 \mathrm{~min}$. Then $20 \mu \mathrm{l}$ of supernatant was taken out and mixed with $1980 \mu 1 \mathrm{~PB}\left(0.1 \mathrm{M}, \mathrm{pH}\right.$ 7.4). One $\mathrm{ml}$ of $\mathrm{H}_{2} \mathrm{O}_{2}(30 \mathrm{mM})$ was added to it and absorbance of test sample was taken at $240 \mathrm{~nm}$ against blank having mixture of PB and tissue homogenate only. Activity of catalase was calculated using the molar extinction coefficient of $43.6 \mathrm{~cm}^{-1}$ (Aebi et al., 1974). mmoles of $\mathrm{H}_{2} \mathrm{O}_{2}$ decomposed $/ \mathrm{min} / \mathrm{mg}$ protein was calculated with formula as $(\Delta \mathrm{A} /$ $\min \times 1000 \times 3) /(43.6 \times \mathrm{mg}$ protein in sample $) . \Delta \mathrm{A} / \mathrm{min}$ is mean absorbance change per minute.

\subsubsection{GSH level in blood}

Blood lysate $(10 \mu \mathrm{l})$ was mixed with $2970 \mu \mathrm{l}$ of PB $(0.1 \mathrm{M} \mathrm{PB}, \mathrm{pH}$ $7.5)$ in a test tube and dTNB $(20 \mu 1,30 \mathrm{mM})$ was added in to it. The mixture was allowed for reaction up to $45 \mathrm{~min}$ and absorbance was taken at $412 \mathrm{~nm}$ against blank having mixture of PB and blood lysate only without dTNB using spectrophotometer. Concentration of GSH was expressed in molar (Ellman, 1959).

\subsubsection{GSH levels in pancreas, liver and kidney tissues}

Tissue samples $(0.5 \mathrm{~g})$ of liver and kidney were homogenized using $1 \mathrm{ml} \mathrm{PB}(0.1 \mathrm{M}, \mathrm{pH} 7.4)$. Tissue homogenate $(0.5 \mathrm{ml})$ was added with equal volume of $20 \%$ trichloroacetic acid (TCA) containing $1 \mathrm{mM}$ EDTA for precipitation of the tissue proteins. The mixture was allowed to stand for $5 \mathrm{~min}$ prior to centrifugation for $10 \mathrm{~min}$ at $10,000 \mathrm{rpm}$. The supernatant $(200 \mu \mathrm{l})$ then transferred to a new set of test tubes and added with $1.8 \mathrm{ml}$ of the Ellman's reagent $(5,50-$ dithiobis-2-nitrobenzoic acid $(0.1 \mathrm{mM})$ prepared in $0.1 \mathrm{M}$ phosphate buffer with $1 \%$ of sodium citrate solution). All test tubes were made up to the volume of $2 \mathrm{ml}$. After completion of the total reaction, absorbance was measured at $412 \mathrm{~nm}$ against blank having mixture of PB and supernatant. Absorbance values were compared with a standard curve generated from known concentration of GSH (Ellman, 1959). 


\subsection{Pathological examination}

All rats were humanely sacrificed using $\mathrm{CO}_{2}$ and dressed on $29^{\text {th }}$ day of the experiment in a confined disinfected laboratory and were subjected to gross pathological examination by systemic approach. Major organs like, pancreas, liver, spleen, kidney, heart and lungs were collected in $10 \%$ formalin for histopathological analysis. The formalin fixed tissues were subjected to paraffin wax embedding for tissue sectioning. Sections of each tissue collected were cut at 6-8 microns thickness with automatic section cutting machine, semiautomated rotary microtome (Leica Biosystems, Germany) and were stained with hematoxylin and eosin (H and E) stain (Luna, 1968). The $\mathrm{H}$ and $\mathrm{E}$ stained slides were observed under microscope and microscopic pathological lesions were recorded.

\subsection{Statistical analysis}

All numerical data were presented as Means \pm standard error (SE) and have been subjected to statistical analysis. Data were analyzed statistically by ANOVA, followed by Duncan's multiple range test (DMRT) to observe difference among the means of each parameter in different groups (Snedecor and Cochran, 1982).

\section{Results and Discussion}

\subsection{Symptoms, body weight and feed consumption}

After induction of diabetes with STZ, symptoms like dullness, sluggish movement, weight loss, polyuria, polydipsia and polyphagia were observed in rats of diabetic control group. Four animals of diabetic control group showed signs of polyuria and progressive reduction in body weight. These symptoms were mild to moderate in all other treatment groups except normal control group. Reduction of body weight in diabetes might be due to breakdown of tissue proteins in diabetic rats (Andulla and Varadacharyulu, 2003).

In our study, feed consumption was progressively increased in diabetic control rats (Figure 1). The feed consumption in diabetic rats treated with glibenclamide was significantly lower during $3^{\text {rd }}$ and $4^{\text {th }}$ week of experiment as compared to those observed in diabetic control group. The increased feed consumption in diabetic rats was not reduced with treatment of PHEM during $1^{\text {st }}, 2^{\text {nd }}$ and $3^{\text {rd }}$ week of experiment. However, the mean value of feed consumption in diabetic rats treated with PHEM was reduced significantly $(p<0.05)$ during $4^{\text {th }}$ week of experimental period. This finding is supported by previous reports by Deepak et al. (2006) and Chaturvedi (2005) that extract of Gymnema sylvestre (Retz.) Schult., and Momordica charantiaL. alter the feed intake. Higher body weight was observed at the end of study period in $\mathrm{C} 1, \mathrm{C} 2$ and $\mathrm{C} 3$ experimental animal groups (Figure 2). Body weight was significantly $(p<0.05)$ lower in rats treated with high dose of PHEM at the end of experimental period and the results obtained are in agreement with findings of
Sujin et al. (2008) and Abdullah et al. (2007) that the administration of Gymnema sylvestre (Retz.) Schult.,and Tinospora cordifolia (Willd.) Miers herbal extracts reduces the body weight in diabetic rats, respectively. Kumar et al. (2008) reported that water soluble fraction of Syzygium cumini (L.) Skeels extract $(120 \mathrm{mg} / \mathrm{kg}$, p.o. for 21 days) in streptozotocin induced diabetic rats reduced the body weight.

\subsection{Glucose levels}

Streptozotocin (STZ) enters the pancreatic cell via a glucose transporter-GLUT2 (Glucose transporter 2) and causes alkylation of DNA. Further, it has been reported that STZ induces activation of poly adenosine diphoshate ribosylation and nitric oxide release, as a result of STZ action; pancreatic cells are destroyed by necrosis and finally induce insulin dependent diabetes (Patel et al., 2006). After diabetes induction with STZ, the blood glucose levels in rats of different groups were progressively increased up to 4 weeks during the experiment but treatment with glibenclamide and PHEM for a period of 28 days after induction of diabetes significantly $(p<0.05)$ reduced blood glucose level especially at $4^{\text {th }}$ week (Table 1). xBlood glucose levels were reduced up to 41.97 and $35.48 \%$ at day 29 compared to those values on day 22 in diabetic rats treated with PHEM at 100 and $200 \mathrm{mg} / \mathrm{kg}$ for 28 days, respectively. However, the blood glucose levels in diabetic rats treated with glibenclamide were lower at day 15, 22 and 29 compared to those values of rats treated with PHEM at both doses which indicates satisfactory antidiabetic effect of glibenclamide. Surprisingly, dose of STZ used in the study produced high level of blood glucose in the present study but the mixture prepared from individual plant extract and administered in diabetic rats showed remarkable result related to reduction on blood glucose level on day 29 of experiment which demonstrated its efficacy in diabetes. Eyo et al. (2011), Chetan et al. (2012), Khedekar et al. (2015), Rajesh et al. (2015), Kumar et al. (2008) and Perumal et al. (2015) also reported hypoglycemic action of A. cepa, T. foenum-graecum, $T$. cordifolia, G. sylvestre, S. cumini and M. charantia plant extracts, respectively but those were observed at high dose. Presence of Smethylcysteine, kaempferol-3-O- $\beta-\mathrm{D} \quad 6\{\mathrm{P}$-coumaroyl $\}$ glucopyranoside and flavonoids in A. cepa (Ikechukwu and Ifeanyi, 2016); trigonelline, trigocoumarin, and trimecoumarine alkaloids in T. foenum-graecum (Al-Habori and Raman, 1998); tannins, saponins, and steroids in T. cordifolia (Singh et al., 2003); gurmarin, gymnemanol and gymnemic acids in G. sylvestre (Rao and Sinsheimer, 1971); mycaminose, jamboline and gallic acid in S. cumini (Sharma et al., 2008); charantin, insulin-like peptides and alkaloids in M. charantia (Raman and Lau, 1996), have been reported to be responsible for such property.

Table 1: Blood glucose $(\mathrm{mg} / \mathrm{dl})$ levels at different time interval in different treatment groups

\begin{tabular}{|c|c|c|c|c|}
\hline Group & $\begin{array}{c}\text { Day 0 } \\
(\text { Mean } \pm \text { SE) }\end{array}$ & $\begin{array}{c}\text { Day 15 } \\
(\text { Mean } \pm \text { SE) }\end{array}$ & $\begin{array}{c}\text { Day 22 } \\
(\text { Mean } \pm \text { SE })\end{array}$ & $\begin{array}{c}\text { Day 29 } \\
(\text { Mean } \pm \text { SE) }\end{array}$ \\
\hline C1 & $93.17 \pm 5.08^{\mathrm{a}}$ & $111.33 \pm 5.33^{\mathrm{a}}$ & $106.67 \pm 8.2^{\mathrm{a}}$ & $90.83 \pm 3.50^{\mathrm{a}}$ \\
\hline $\mathrm{C} 2$ & $289.33 \pm 62.28^{\mathrm{b}}$ & $368.00 \pm 51.28^{\mathrm{b}}$ & $442.50 \pm 45.4^{\mathrm{b}}$ & $419.00 \pm 44.69^{\mathrm{c}}$ \\
\hline C3 & $290.33 \pm 43.84^{\mathrm{b}}$ & $226.17 \pm 41.25^{\mathrm{ab}}$ & $190.50 \pm 26.7^{\mathrm{a}}$ & $167.50 \pm 28.79^{\mathrm{ab}}$ \\
\hline T 1 & $282.33 \pm 34.07^{\mathrm{b}}$ & $404.50 \pm 53.60^{\mathrm{b}}$ & $518.67 \pm 81.6^{\mathrm{b}}$ & $301.00 \pm 37.99^{\mathrm{bc}}$ \\
\hline T2 & $288.67 \pm 27.84^{\mathrm{b}}$ & $410.50 \pm 59.42^{\mathrm{b}}$ & $450.00 \pm 71.7^{\mathrm{b}}$ & $290.33 \pm 42.76^{\mathrm{bc}}$ \\
\hline
\end{tabular}

Values with different superscript in a column were significantly different $(p<0.05)$. 


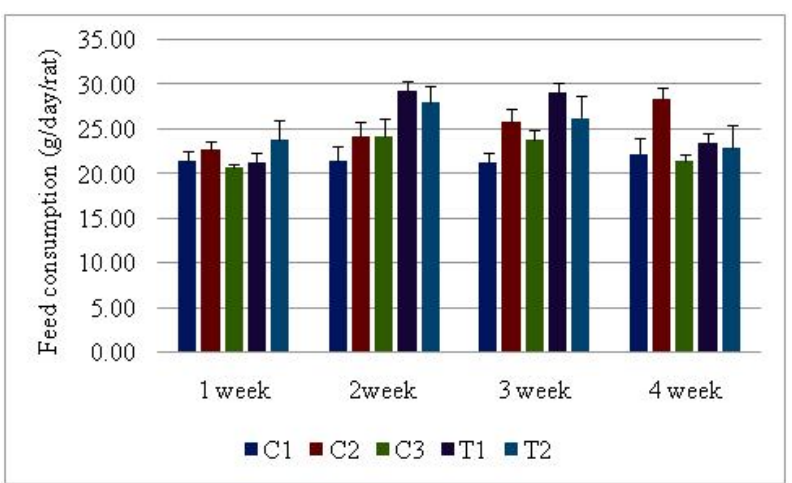

Figure 1: The average feed consumption (g/day/rat) of experimental animals in different groups.

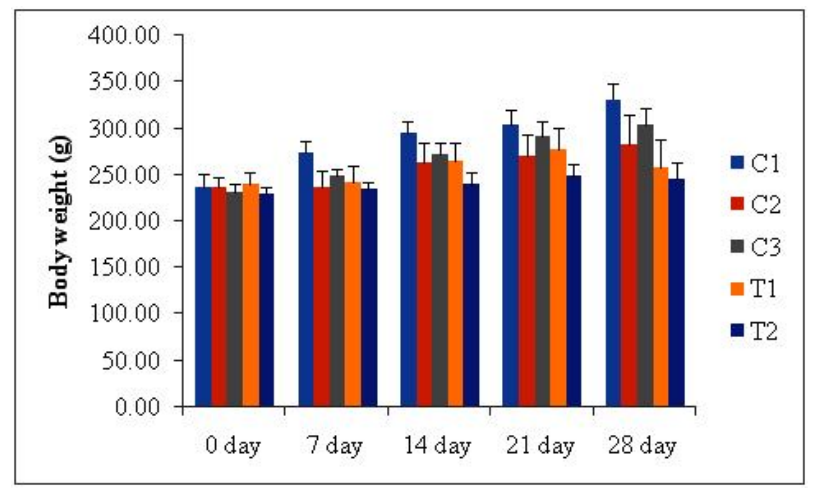

Figure 2: Body weight $(\mathrm{g})$ of experimental animals of different groups.

On day 15 , oral glucose tolerance test (OGTT) was carried out to evaluate the status of diabetic condition and it was observed that the blood glucose levels in rats of different treatment groups were significantly $(p<0.05)$ higher at $30 \mathrm{~min}$ after oral glucose administration at dose of $2 \mathrm{~g} / \mathrm{kg}$ as compared to normal rats (Figure 3 ). The values of glucose levels were significantly $(p<0.05)$ reduced at 90 min and found significantly $(p<0.05)$ lower at $120 \mathrm{~min}$ after glucose load which were comparable to the values at pre-glucose administration in $\mathrm{C} 1$ and $\mathrm{C} 3$ groups. The slight higher blood glucose levels in group $\mathrm{C} 2, \mathrm{~T} 1$ and $\mathrm{T} 2$ indicates inability of PHEM to reduce the increased blood glucose level at day 15. This result was supported by no effect of PHEM treatment on blood glucose level up to $3^{\text {rd }}$ week of the experiment.

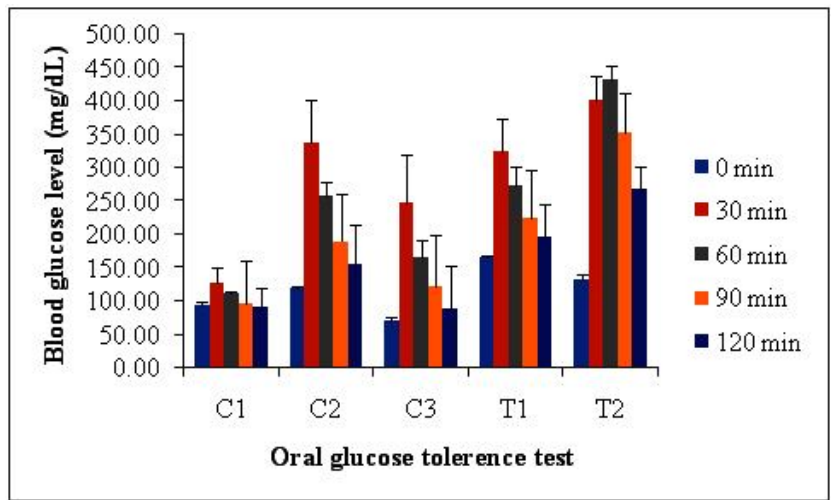

Figure 3: Glucose levels $(\mathrm{mg} / \mathrm{dl})$ in rats under oral glucose tolerance test (OGTT) at day 15 of experiment.

\subsection{Haematological and biochemical parameters}

Haematological parameters like Hb, PCV, TEC, TLC, MCV, MCHC, $\mathrm{MCH}$ and DLC were not significantly altered in diabetic rats (Table 2 ). The mean values of $\mathrm{Hb}, \mathrm{PCV}$ and TEC were significantly higher in PHEM treated rats as compared to normal and diabetic control rats which showed little positive effect of PHEM in diabetes. Punithavathi et al. (2008) reported increased level of glycated hemoglobin in diabetic rats with subsequent decrease in total hemoglobin. In diabetes mellitus, hyperglycemia is accompanied with dyslipidemia that is characterized by increase in TC, LDL cholesterol and decrease in HDL cholesterol. The abnormally high concentration of serum lipids (TG) in diabetics is mainly due to increase in the mobilization of free fatty acids from the peripheral fat depots (Bopama et al., 1997; Gupta et al., 2009). In the present study, mean levels of TC and TG were non-significantly $(p>0.05)$ increased and level of HDL-cholesterol was slightly decreased with significant $(p<0.05)$ increase in level of LDL-cholesterol in diabetic control group as compared to other treatment groups (Table 3 ). Mean values of TC and TG were lower in both glibenclamide and PHEM treated groups. Also, mean values of HDL-cholesterol were significantly $(p<0.05)$ increased, while mean values of LDLcholesterol were significantly $(p<0.05)$ decreased in both glibenclamide as well as in PHEM treated groups, showed their potential to have hypolipidemic action. Ozougwu (2011) also reported a significant dose dependent lowering of serum total lipid levels in streptozotocin induced diabetic rats when treated with A. cepa. Hypolipidaemic effect of A. cepa may be related to its active ingredient, allyl propyl disulphide (Kumari and Augusti, 2002). Presence of trigonelline in fenugreek seeds might be responsible for hypolipidaemic action which mediates its action by increased excretion of cholesterol and total bile acids into the feces (Muraki et al., 2011). Also presence of gymnemic acids in $G$. sylvestre (Grijesh et al., 2009); mycaminose in S. cumini (Kumar et al., 2008) and charantin in $M$, charantia (Chaturvedi, 2005) might be responsible for hypolipidaemic effect of PHEM in the present experiment at lower dose in combination.

In biochemical parameters, non-significant increase in the values of ALT and AST has been observed in diabetic control rats (Table 3), which might be due to increased cell membrane permeability or cell membrane damage of hepatocytes. However, PHEM treatment significantly reduced the elevated levels of AST in diabetic rats. Supporting to our findings, Arkkila et al. (2001) reported elevated activities of serum aminotransferases (ALT, AST, ALP) in liver and cardiovascular diseases are observed more frequently among people with diabetes. Increased levels of ALT and AST in diabetic rats indicates that diabetes may induce hepatic dysfunction. Supporting to our findings, it has been reported by Ohaeri (2001) that structure of liver was altered in diabetic rats. Therefore, the increase in the activities of ALT, AST and ALP in serum may be mainly due to the leakage of these enzymes from the liver cytosol into the blood stream (Concepcion et al., 1993). ALT and AST levels in diabetic rats treated with PHEM $\left(\mathrm{T}_{1}\right.$ and $\left.\mathrm{T}_{2}\right)$ were lower as compared to those in diabetic rats which indicate partial corrective effect by herbal treatment in diabetic rats in the present study. Results obtained from the present study are clearly in agreement with previous reports by Renuka et al. (2009), Stanely et al. (2000) and Aziza et al. (2013) related to hepatoprotective activity of $T$. foenumgraecum, $T$. cordifolia, $G$. sylvestre herbal extracts, respectively in restoring back the elevated levels of ALT, AST and ALP in diabetes. 
However, level of ALP in diabetic rats treated with PHEM was not significantly reversed which might be due to differences of doses or amount uses in the study. The mean BUN value $(\mathrm{mg} / \mathrm{dl})$ was increased in diabetic rats which was significantly lower in glibenclamide treated rats. However, the mean BUN (mg/dl) level of PHEM treated animals at day 29 of experiment were not significantly corrected which indicate partial effect of PHEM on kidney damage caused by STZ in rats. The mean value of creatinine $(\mathrm{mg} / \mathrm{dl})$ in diabetic control group was non-significantly $(p>0.05)$ increased as compared to control group. No significant alteration $(p>0.05)$ was observed in creatinine levels of rats of all other treatment groups as compared to diabetic control group. The mean value of bilirubin $(\mathrm{mg} / \mathrm{dl})$ in diabetic control group was nonsignificantly $(p>0.05)$ increased as compared to control group. Whereas, the mean values of bilirubin $(\mathrm{mg} / \mathrm{dl})$ were non-significantly $(p>0.05)$ lower in glibenclamide as well as in PHEM treated groups.

Table 2: Hematological parameters in rats of different treatment groups

\begin{tabular}{|l|c|c|c|c|c|}
\hline \multirow{2}{*}{ Parameters } & \multicolumn{5}{|c|}{ Treatment groups } \\
\cline { 2 - 6 } & C1 & C2 & C3 & T1 & T2 \\
\hline HB (g/dl) & $17.10 \pm 0.21^{\mathrm{a}}$ & $18.51 \pm 0.43^{\mathrm{abc}}$ & $18.06 \pm 0.45^{\mathrm{ab}}$ & $19.98 \pm 0.61^{\mathrm{bc}}$ & $20.13 \pm 0.48^{\mathrm{c}}$ \\
\hline PCV(\%) & $46.71 \pm 0.42^{\mathrm{a}}$ & $50.88 \pm 1.04^{\mathrm{ab}}$ & $49.33 \pm 1.14^{\mathrm{ab}}$ & $51.33 \pm 1.53^{\mathrm{b}}$ & $52.52 \pm 1.57^{\mathrm{b}}$ \\
\hline TEC $\left(10^{6} / \mu \mathrm{l}\right)$ & $9.28 \pm 0.18^{\mathrm{a}}$ & $10.12 \pm 0.26^{\mathrm{ab}}$ & $9.81 \pm 0.23^{\mathrm{ab}}$ & $10.11 \pm 037^{\mathrm{ab}}$ & $10.70 \pm 0.31^{\mathrm{b}}$ \\
\hline WBC $\left(10^{3} / \mathrm{cmm}\right)$ & $9.94 \pm 1.20^{\mathrm{bc}}$ & $8.60 \pm 0.28^{\mathrm{abc}}$ & $11.97 \pm 1.62^{\mathrm{c}}$ & $7.37 \pm 1.16^{\mathrm{ab}}$ & $5.22 \pm 1.00^{\mathrm{a}}$ \\
\hline MCV (fl) & $50.39 \pm 0.63^{\mathrm{a}}$ & $50.16 \pm 0.60^{\mathrm{a}}$ & $50.50 \pm 0.76^{\mathrm{a}}$ & $50.66 \pm 0.42^{\mathrm{a}}$ & $49.00 \pm 0.52^{\mathrm{a}}$ \\
\hline MCHC $(\%)$ & $36.65 \pm 0.43^{\mathrm{a}}$ & $36.80 \pm 0.28^{\mathrm{a}}$ & $36.45 \pm 0.20^{\mathrm{a}}$ & $38.98 \pm 1.04^{\mathrm{b}}$ & $38.41 \pm 0.33^{\mathrm{ab}}$ \\
\hline MCH (pg) & $18.46 \pm 0.31^{\mathrm{a}}$ & $18.48 \pm 0.15^{\mathrm{a}}$ & $18.40 \pm 0.33^{\mathrm{a}}$ & $19.80 \pm 0.59^{\mathrm{b}}$ & $18.85 \pm 0.28^{\mathrm{ab}}$ \\
\hline Lymphocyte $(\%)$ & $84.30 \pm 2.11^{\mathrm{a}}$ & $83.48 \pm 1.78^{\mathrm{a}}$ & $73.00 \pm 6.64^{\mathrm{a}}$ & $77.41 \pm 2.73^{\mathrm{a}}$ & $72.25 \pm 8.56^{\mathrm{a}}$ \\
\hline Neutrophils $(\%)$ & $12.85 \pm 1.67^{\mathrm{a}}$ & $13.13 \pm 1.16^{\mathrm{a}}$ & $23.33 \pm 5.75^{\mathrm{a}}$ & $17.95 \pm 1.14^{\mathrm{a}}$ & $24.65 \pm 6.73^{\mathrm{a}}$ \\
\hline Eosinophil (\%) & $0.33 \pm 0.21^{\mathrm{a}}$ & $0.33 \pm 0.21^{\mathrm{a}}$ & $0.17 \pm 0.17^{\mathrm{a}}$ & $0.33 \pm 0.21^{\mathrm{a}}$ & $0.17 \pm 0.17^{\mathrm{a}}$ \\
\hline Monocytes $(\%)$ & $2.85 \pm 1.10^{\mathrm{a}}$ & $3.03 \pm 2.07^{\mathrm{a}}$ & $3.63 \pm 1.61^{\mathrm{a}}$ & $4.65 \pm 2.56^{\mathrm{a}}$ & $3.10 \pm 1.99^{\mathrm{a}}$ \\
\hline
\end{tabular}

Values with different superscript in a row were significantly different $(p>0.05)$.

Table 3: Biochemical parameters in rats of different treatment groups

\begin{tabular}{|l|c|c|c|c|c|}
\hline \multirow{2}{*}{ Parameters } & \multicolumn{5}{|c|}{ Treatment groups } \\
\cline { 2 - 6 } & C1 & C2 & C3 & T1 & T2 \\
\hline Total cholesterol (mg/dl) & $129.67 \pm 11.51^{\mathrm{a}}$ & $151.00 \pm 18.50^{\mathrm{a}}$ & $134.67 \pm 12.93^{\mathrm{a}}$ & $140.17 \pm 13.16^{\mathrm{a}}$ & $142.83 \pm 7.88^{\mathrm{a}}$ \\
\hline Triglycerides (mg/dl) & $116.50 \pm 9.67^{\mathrm{a}}$ & $123.33 \pm 16.45^{\mathrm{a}}$ & $114.17 \pm 6.94^{\mathrm{a}}$ & $116.00 \pm 11.69^{\mathrm{a}}$ & $108.50 \pm 14.66^{\mathrm{a}}$ \\
\hline HDL-cholesterol (mg/dl) & $45.76 \pm 3.79^{\mathrm{a}}$ & $42.36 \pm 3.98^{\mathrm{a}}$ & $48.68 \pm 9.01^{\mathrm{a}}$ & $71.27 \pm 7.16^{\mathrm{b}}$ & $63.10 \pm 4.48^{\mathrm{ab}}$ \\
\hline LDL-cholesterol (mg/dl) & $17.27 \pm 2.45^{\mathrm{ab}}$ & $21.03 \pm 1.18^{\mathrm{b}}$ & $18.81 \pm 3.86^{\mathrm{b}}$ & $15.52 \pm 2.98^{\mathrm{ab}}$ & $9.45 \pm 1.59^{\mathrm{a}}$ \\
\hline AST (IU/l) & $136.33 \pm 7.28^{\mathrm{ab}}$ & $148.24 \pm 14.39^{\mathrm{b}}$ & $127.22 \pm 15.75^{\mathrm{ab}}$ & $119.87 \pm 8.19^{\mathrm{ab}}$ & $112.59 \pm 8.96^{\mathrm{a}}$ \\
\hline ALT (IU/) & $41.13 \pm 2.64^{\mathrm{a}}$ & $60.39 \pm 7.32^{\mathrm{a}}$ & $55.12 \pm 12.68^{\mathrm{a}}$ & $52.65 \pm 9.10^{\mathrm{a}}$ & $45.79 \pm 4.90^{\mathrm{a}}$ \\
\hline ALP (IU/l) & $169.33 \pm 7.60^{\mathrm{a}}$ & $349.85 \pm 70.12^{\mathrm{ab}}$ & $299.02 \pm 93.02^{\mathrm{ab}}$ & $476.75 \pm 80.88^{\mathrm{b}}$ & $403.58 \pm 92.33^{\mathrm{ab}}$ \\
\hline BUN (mg/dl) & $25.00 \pm 1.05^{\mathrm{ab}}$ & $40.70 \pm 5.98^{\mathrm{b}}$ & $22.48 \pm 1.87^{\mathrm{a}}$ & $42.92 \pm 8.48^{\mathrm{b}}$ & $41.42 \pm 3.85^{\mathrm{b}}$ \\
\hline Creatinine (mg/dl) & $0.43 \pm 0.05^{\mathrm{a}}$ & $0.49 \pm 0.08^{\mathrm{a}}$ & $0.40 \pm 0.09^{\mathrm{a}}$ & $0.60 \pm 0.10^{\mathrm{a}}$ & $0.46 \pm 0.11^{\mathrm{a}}$ \\
\hline Total protein (g/dl) & $6.51 \pm 0.10^{\mathrm{a}}$ & $6.17 \pm 0.34^{\mathrm{a}}$ & $6.37 \pm 0.13^{\mathrm{a}}$ & $6.34 \pm 0.09^{\mathrm{a}}$ & $6.35 \pm 0.21^{\mathrm{a}}$ \\
\hline Albumin (g/dl) & $3.48 \pm 0.03^{\mathrm{b}}$ & $3.08 \pm 0.16^{\mathrm{ab}}$ & $3.06 \pm 0.12^{\mathrm{a}}$ & $3.25 \pm 0.05^{\mathrm{ab}}$ & $3.01 \pm 0.17^{\mathrm{a}}$ \\
\hline Globulin (g/dl) & $3.03 \pm 0.09^{\mathrm{a}}$ & $3.09 \pm 0.17^{\mathrm{a}}$ & $3.31 \pm 0.15^{\mathrm{a}}$ & $3.09 \pm 0.07^{\mathrm{a}}$ & $3.34 \pm 0.23^{\mathrm{a}}$ \\
\hline Total bilirubin (mg/dl) & $0.29 \pm 0.01^{\mathrm{a}}$ & $0.60 \pm 0.14^{\mathrm{a}}$ & $0.44 \pm 0.14^{\mathrm{a}}$ & $0.46 \pm 0.08^{\mathrm{a}}$ & $0.41 \pm 0.17^{\mathrm{a}}$ \\
\hline
\end{tabular}

Values with different superscript in a row were significantly different $(p<0.05)$. 
Table 4: Mean values of organ weight (pancreas, liver, kidneys, heart and spleen) in ratsunder different treatment groups

\begin{tabular}{|l|c|c|c|c|c|}
\hline \multirow{2}{*}{ Organ } & \multicolumn{5}{|c|}{ Organ weight (g) } \\
\cline { 2 - 6 } & $\mathbf{C 1}$ & $\mathbf{C 2}$ & $\mathbf{C 3}$ & T1 & T2 \\
\hline Pancreas & $1.75 \pm 0.14^{\mathrm{a}}$ & $1.31 \pm 0.27^{\mathrm{a}}$ & $1.41 \pm 0.16^{\mathrm{a}}$ & $1.31 \pm 0.15^{\mathrm{a}}$ & $1.38 \pm 0.13^{\mathrm{a}}$ \\
\hline Liver & $12.30 \pm 1.26^{\mathrm{a}}$ & $10.82 \pm 1.35^{\mathrm{a}}$ & $12.27 \pm 0.53^{\mathrm{a}}$ & $13.10 \pm 1.28^{\mathrm{a}}$ & $10.78 \pm 1.28^{\mathrm{a}}$ \\
\hline Kidneys & $2.25 \pm 0.13^{\mathrm{a}}$ & $2.50 \pm 0.13^{\mathrm{a}}$ & $2.51 \pm 0.13^{\mathrm{a}}$ & $2.73 \pm 0.22^{\mathrm{a}}$ & $2.56 \pm 0.25^{\mathrm{a}}$ \\
\hline Heart & $1.10 \pm 0.06^{\mathrm{a}}$ & $1.05 \pm 0.13^{\mathrm{a}}$ & $1.08 \pm 0.05^{\mathrm{a}}$ & $1.04 \pm 0.11^{\mathrm{a}}$ & $0.89 \pm 0.07^{\mathrm{a}}$ \\
\hline Spleen & $0.61 \pm 0.03^{\mathrm{a}}$ & $0.51 \pm 0.07^{\mathrm{a}}$ & $0.67 \pm 0.10^{\mathrm{a}}$ & $0.47 \pm 0.08^{\mathrm{a}}$ & $0.44 \pm 0.08^{\mathrm{a}}$ \\
\hline
\end{tabular}

Values with different superscript in a row were significantly different $(p<0.05)$.

Table 5: SOD activity in different samples collected fromrats under different treatments

\begin{tabular}{|l|c|c|c|c|c|}
\hline \multirow{2}{*}{ Sample } & \multicolumn{5}{|c|}{ SOD (U/ml) } \\
\cline { 2 - 6 } & C1 & C2 & C3 & T1 & T2 \\
\hline Serum & $11.05 \pm 0.55^{\mathrm{a}}$ & $8.67 \pm 0.79^{\mathrm{b}}$ & $9.52 \pm 1.06^{\mathrm{ab}}$ & $11.62 \pm 0.64^{\mathrm{a}}$ & $10.10 \pm 1.01^{\mathrm{a}}$ \\
\hline Liver & $55.10 \pm 9.11^{\mathrm{a}}$ & $43.54 \pm 4.46^{\mathrm{a}}$ & $53.84 \pm 4.96^{\mathrm{a}}$ & $48.57 \pm 4.98^{\mathrm{a}}$ & $61.12 \pm 4.94^{\mathrm{a}}$ \\
\hline Kidney & $42.52 \pm 2.55^{\mathrm{ab}}$ & $41.50 \pm 1.36^{\mathrm{a}}$ & $51.02 \pm 3.16^{\mathrm{c}}$ & $52.04 \pm 1.56^{\mathrm{c}}$ & $49.66 \pm 1.80^{\mathrm{bc}}$ \\
\hline Pancreas & $65.99 \pm 4.55^{\mathrm{a}}$ & $59.76 \pm 6.02^{\mathrm{a}}$ & $67.59 \pm 3.48^{\mathrm{a}}$ & $65.44 \pm 2.79^{\mathrm{a}}$ & $69.15 \pm 5.69^{\mathrm{a}}$ \\
\hline
\end{tabular}

Values with different superscript in a row were significantly different $(p<0.05)$.

Table 6: Catalase activity in different samples collected from rats under different treatments

\begin{tabular}{|l|c|c|c|c|c|}
\hline \multirow{2}{*}{ Sample } & \multicolumn{5}{|c|}{ Catalase } \\
\cline { 2 - 6 } & C1 & C2 & C3 & T1 & T2 \\
\hline Blood (molar/min) & $2.007 \pm 0.151^{\mathrm{a}}$ & $1.990 \pm 0.144^{\mathrm{a}}$ & $2.134 \pm 0.173^{\mathrm{a}}$ & $2.070 \pm 0.110^{\mathrm{a}}$ & $2.271 \pm 0.139^{\mathrm{a}}$ \\
\hline Liver (U/mg protein) & $0.057 \pm 0.006^{\mathrm{ab}}$ & $0.043 \pm 0.008^{\mathrm{a}}$ & $0.057 \pm 0.006^{\mathrm{ab}}$ & $0.077 \pm 0.008^{\mathrm{b}}$ & $0.075 \pm 0.007^{\mathrm{b}}$ \\
\hline Kidney (U/mg protein) & $0.181 \pm 0.015^{\mathrm{a}}$ & $0.157 \pm 0.004^{\mathrm{a}}$ & $0.192 \pm 0.021^{\mathrm{a}}$ & $0.191 \pm 0.017^{\mathrm{a}}$ & $0.188 \pm 0.013^{\mathrm{a}}$ \\
\hline Pancreas (U/mg protein) & $0.465 \pm 0.098^{\mathrm{a}}$ & $0.329 \pm 0.024^{\mathrm{a}}$ & $0.361 \pm 0.038^{\mathrm{a}}$ & $0.331 \pm 0.026^{\mathrm{a}}$ & $0.389 \pm 0.051^{\mathrm{a}}$ \\
\hline
\end{tabular}

Values with different superscript in a row were significantly different $(p<0.05)$.

Table 7: GSH levels in different samples collected from rats under different treatments

\begin{tabular}{|l|l|l|l|l|c|}
\hline \multirow{2}{*}{ Sample } & \multicolumn{5}{c|}{ GSH } \\
\cline { 2 - 6 } & \multicolumn{1}{|c|}{ C1 } & C2 & C3 & T1 & T2 \\
\hline Blood (molar) & $9.42 \pm 0.30^{\mathrm{ab}}$ & $8.52 \pm 0.26^{\mathrm{a}}$ & $9.55 \pm 0.67^{\mathrm{ab}}$ & $10.17 \pm 0.82^{\mathrm{ab}}$ & $10.67 \pm 0.49^{\mathrm{b}}$ \\
\hline Liver $(\mu \mathrm{g} / \mathrm{mg}$ of tissue) & $0.18 \pm 0.01^{\mathrm{a}}$ & $0.14 \pm 0.01^{\mathrm{a}}$ & $0.22 \pm 0.02^{\mathrm{a}}$ & $0.15 \pm 0.02^{\mathrm{a}}$ & $0.17 \pm 0.03^{\mathrm{a}}$ \\
\hline Kidney $(\mu \mathrm{g} / \mathrm{mg}$ of tissue) & $0.28 \pm 0.01^{\mathrm{a}}$ & $0.25 \pm 0.02^{\mathrm{a}}$ & $0.28 \pm 0.01^{\mathrm{a}}$ & $0.25 \pm 0.05^{\mathrm{a}}$ & $0.28 \pm 0.02^{\mathrm{a}}$ \\
\hline Pancreas $(\mu \mathrm{g} / \mathrm{mg}$ of tissue) & $0.19 \pm 0.01^{\mathrm{ab}}$ & $0.16 \pm 0.02^{\mathrm{a}}$ & $0.24 \pm 0.01^{\mathrm{c}}$ & $0.21 \pm 0.01^{\mathrm{bc}}$ & $0.22 \pm 0.01^{\mathrm{bc}}$ \\
\hline
\end{tabular}

Values with different superscript in a row were significantly different $(p<0.05)$. 


\subsection{Weight and gross observations of organs}

Effect of daily oral administration of PHEM (100 and $200 \mathrm{mg} / \mathrm{kg}$, P.O) on organ weight in rats of different experimental groups are presented in Table 4. No significant $(p>0.05)$ alterations in organ weight in any treatment group have been observed as compared to those of control rats. Upon gross examination of pancreas, no appreciable gross lesions in all treatment groups have been observed. Macroscopic examination of liver and kidneys of experimental rats of diabetic control group shown congestion, paleness and slight enlargement. No appreciable macroscopic lesions have been observed in the spleen, heart and lung of rats of different treatment groups.

\subsection{Antioxidant defense system}

The activity of SOD was significantly decreased in serum and nonsignificantly decreased in liver and pancreas of animals, treated with STZ, compared to those observed in control rats. These alterations were not observed in diabetic rats treated with glibenclamide and PHEM at both doses (Table 5). The catalase activity in liver, kidney and pancreas were found non-significantly lower in diabetic control rats compared to those in normal control rats. Compared to diabetic control rats, higher values of catalase activity have been observed in liver (significant) and serum, kidney and pancreas (non-significantly) (Table 6). The levels of GSH in blood, liver, kidney and pancreas were non-significantly lower in diabetic rats compared to those estimated in normal control rats. The values of GSH level in blood, liver, kidney and pancreas were improved in diabetic rats treated with glibenclamide as well as PHEM at both doses (Table 7).

Superoxide dismutase (SOD) belongs to a family of antioxidant enzymes that catalyze the dismutation of superoxide to yield hydrogen peroxide and oxygen. More production of superoxide ion leads to elevation in SOD activity to overcome the auto oxidation and oxidative stress. Catalase is a ubiquitous enzyme which is present in the peroxisomes that catalyzes the decomposition of hydrogen peroxide, a reactive oxygen species, which is a toxic product of both normal aerobic metabolism and pathogenic reactive oxygen species (ROS) production (Kohen and Nyska, 2002). In toxicity condition, the blood catalase utilized more due to production of more ROS. Catalase is inducible enzyme in tissues like liver, kidney and pancreas. During the exposure to xenobiotics, there is more accumulation of chemical in these organs leads to more metabolite production which increase more ROS and oxidative stress. GSH is an intra-cellular reluctant and plays a major role in catalysis, metabolism, and transport. It protects cell against free radicals, peroxides, and other toxic compounds (Aydemir et al., 2000). Several studies have demonstrated that hyperglycemia in STZ induced diabetes has been associated with increased formation of reactive oxygen species (ROS) and oxidative damage to tissue components (Alireza et al., 2009). Also oxidative stress in STZ induced diabetic animals is due to glucose auto-oxidation, protein glycation, formation of advanced glycation products and the polyol pathway that generates free radicals (Atalay and Laaksonen, 2002). Results related to improved oxidative stress markers in diabetic animals treated with PHEM in the present study are in agreement with previous findings reported by Coskun et al. (2005), Xue et al. (2011), Gupta and Sharma. (2011) and Aziza et al. (2013) related to antioxidant effects of A. cepa, T. faenum-graecum, T. cordifolia and Gymnema sylvestre, respectively.

\subsection{Histopathological evaluation}

Histopathological findings in pancreas and kidney of rats of all five groups are shown in Figures $4 \mathrm{a}$ to $4 \mathrm{e}$ and Figures $5 \mathrm{a}$ to $5 \mathrm{e}$, respectively. The histopathological changes of pancreas of rats of diabetic control group $(\mathrm{C} 2)$ revealed degenerative changes with loss of normal architecture of parenchyma. Islets of langerhans were shrunken with loss of its normal cell cord arrangement and degeneration in many of serous acini and islet of langerhans. While histopathological changes in pancreas collected from rats treated with PHEM (higher dose) shown an apparent increase in the size of an islet of langerhans with few cords of normal endocrine cells compared to diabetic control group. Histopathological changes of kidney of diabetic control rats showed increase bowman's capsular space, vacuolar degeneration and necrosis of tubular epithelium. While kidneys of rats treated with PHEM were with less degenerated epithelium in glomeruli as well as tubules compared to diabetic control group. No appreciable histopathological lesions have been observed in the liver, spleen, heart and lung of rats in all treatment groups.

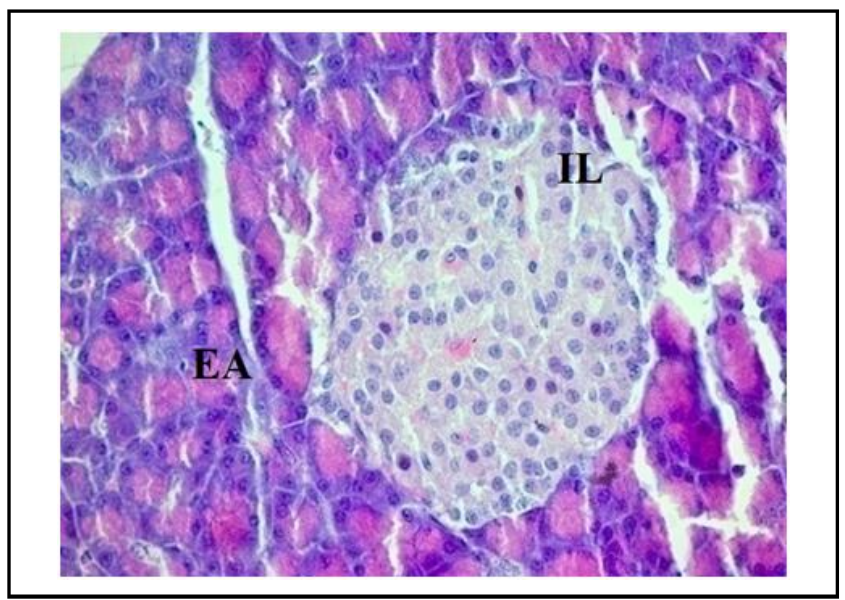

Figure 4(a): Microscopic view of pancreas in control group (C1) showing well-defined islet of langerhans (Il) surrounded by exocrine acini (EA) (H and E stain, 400X).

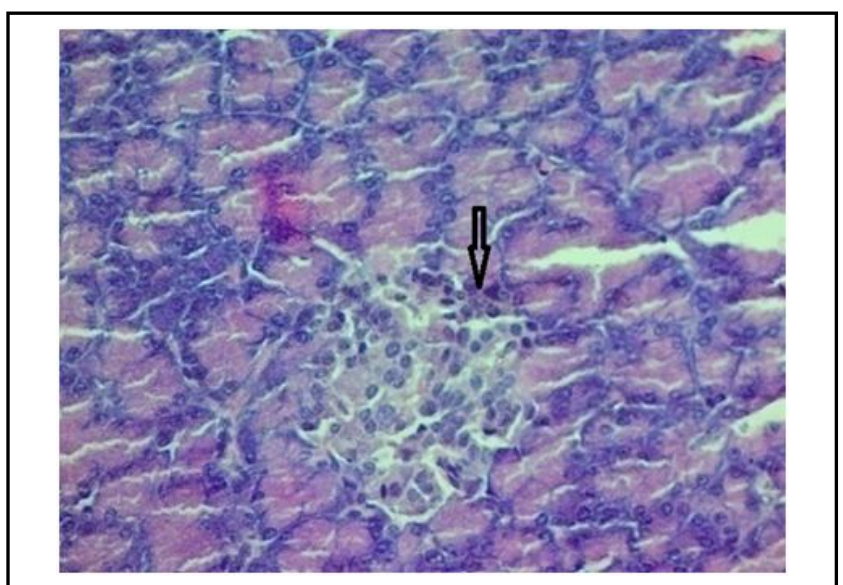

Figure 4(b): Microscopic view of pancreas in diabetic control (C2) group showing shrunken islets of langerhans with loss of its normal cell cord arrangement compare to control group (Arrow) (H and E stain, 400X). 


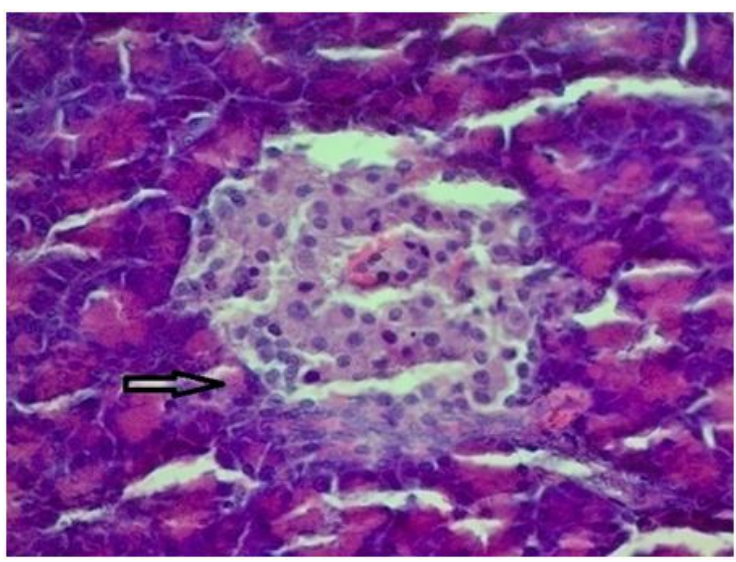

Figure 4(c): Microscopic view of pancreas in glibenclamide treated group (C3) showing an apparent increase in the size of an islet of langerhans (Arrow) (H and E stain, 400X).

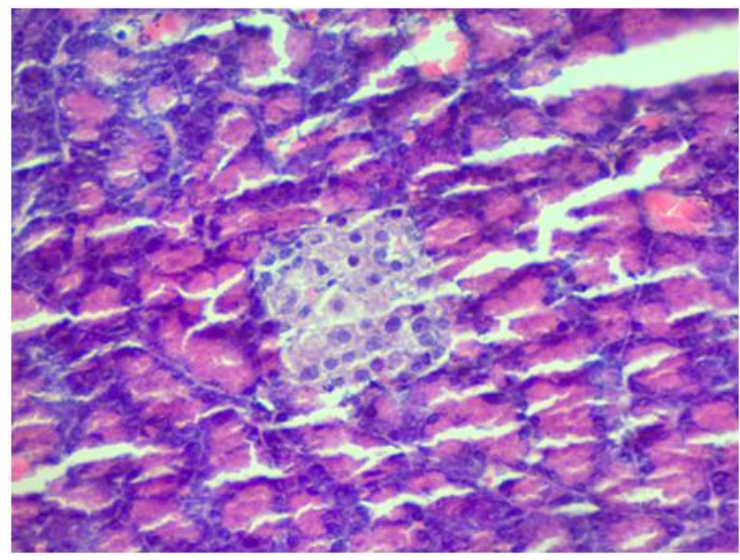

Figure 4(d): Microscopic view of pancreas in PHE treated group (T1) showing moderate cellularity (Arrow) ( $\mathrm{H}$ and $\mathrm{E}$ stain, 400X)

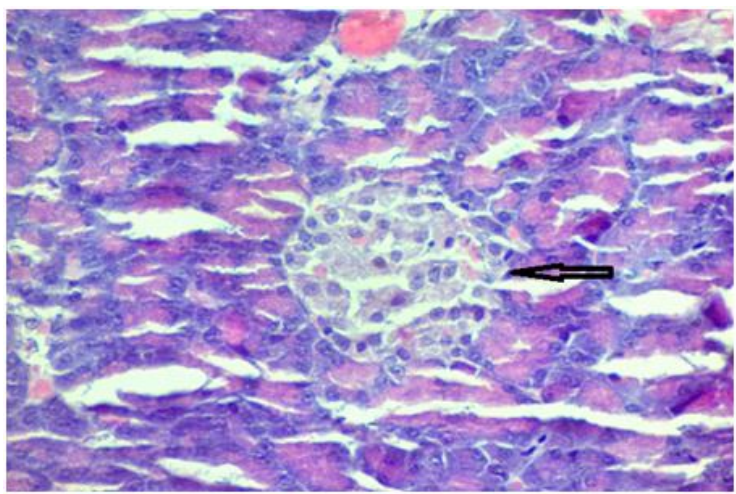

Figure 4(e): Microscopic view of pancreas in PHE treated group (T2) showing an apparent increase in the size of an islet of langerhans (Arrow) (H and E stain, 400X).

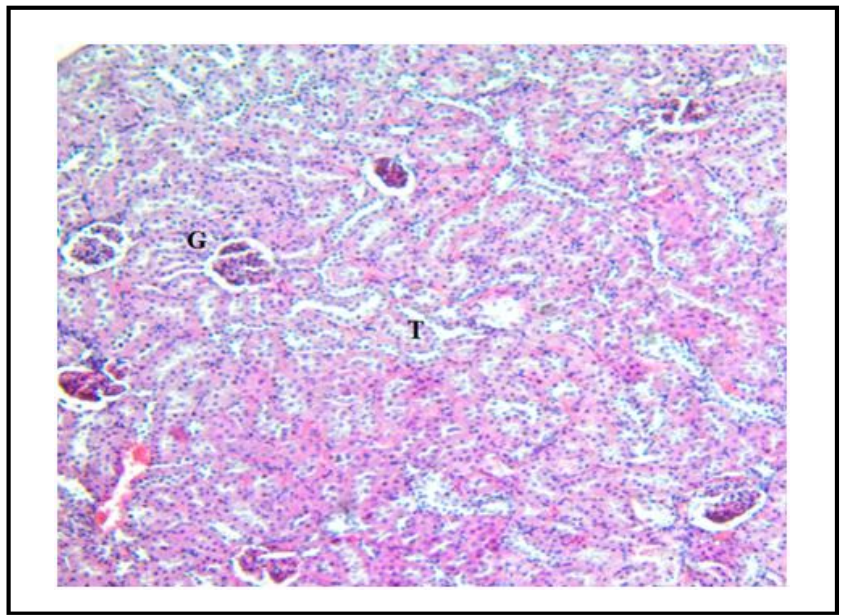

Figure 5(a): Microscopic view of kidney in control group (C1) showing normal architecture of glomeruli $(\mathrm{G})$ as well as tubular (T) epithelium (H and E stain, 100X).

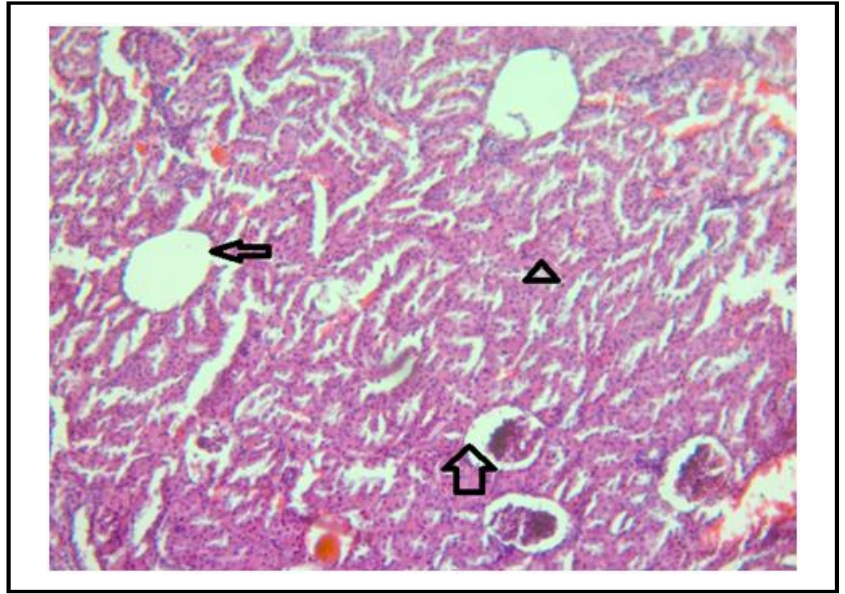

Figure 5(b): Microscopic view of kidney in diabetic group (C2) showing loss of glomerular structure (Thin arrow), increased bowman's capsular space (Thick arrow), vacuolar degeneration and necrosis of tubular epithelium (Arrow head) (H and E stain, 100X).

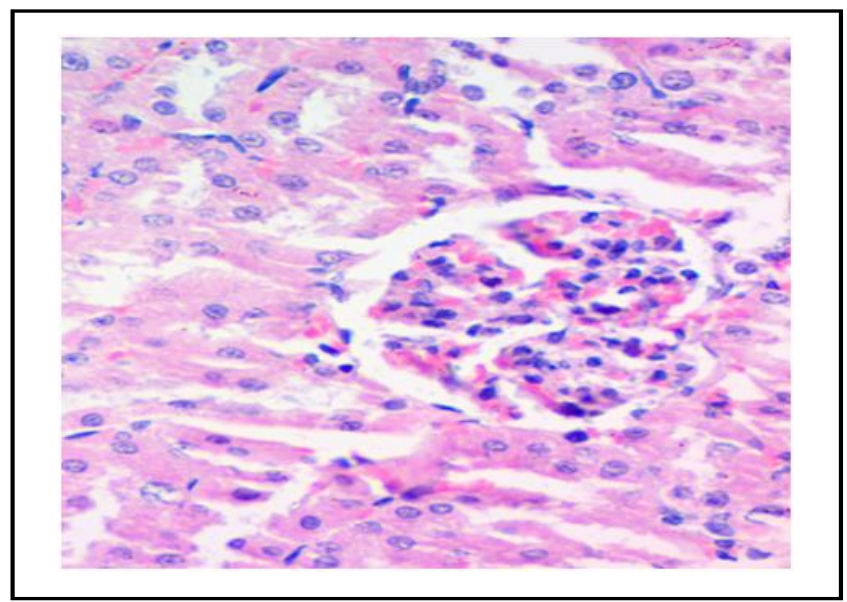

Figure 5(c): Microscopic view of kidney in group C3 showing normal architecture of glomeruli as well as tubular epithelium ( $\mathrm{H}$ and $\mathrm{E}$ stain, 400X). 


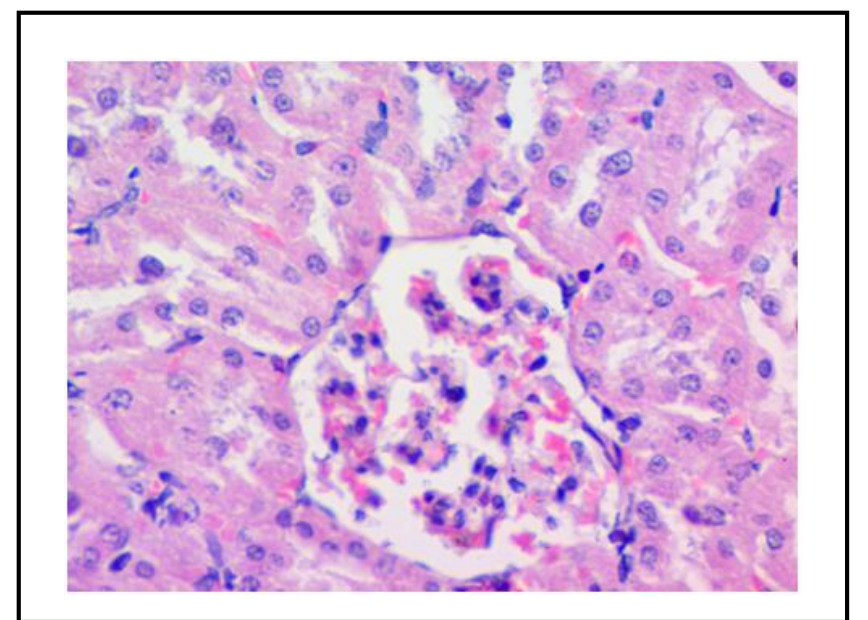

Figure 5(d): Microscopic view of kidney in group $\mathrm{T} 1$ showing normal architecture of glomeruli as well as tubular epithelium ( $\mathrm{H}$ and $\mathrm{E}$ stain, 400X).

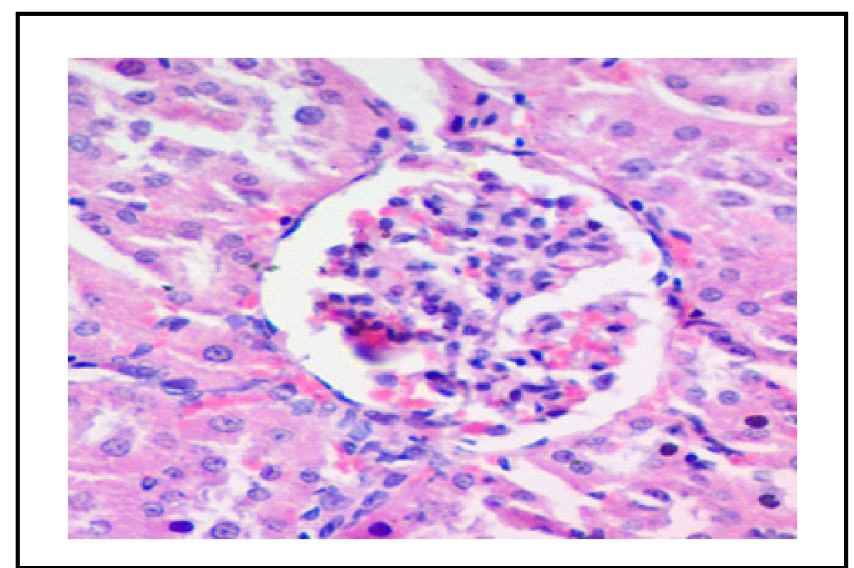

Figure 5(e): Microscopic view of kidney in group T2 showing normal architecture of glomeruli as well as tubular epithelium ( $\mathrm{H}$ and $\mathrm{E}$ stain, 400X).

\section{Conclusion}

Polyherbal extract mixture with equal part of hydro-alcoholic extracts of leaves of G. sylvestre,peels of A. cepa, fruits of M. charantia, stem of T. cordifolia and dried seeds of T. foenum-graecum. and $S$. cumini at $200 \mathrm{mg} / \mathrm{kg}$ showed ameliorating effect against streptozotocin induced alterations in diabetic rats due having active principles with antioxidant potential. Further, efficacy of such extract mixture needs to be evaluated in other models of diabetes along with safety studies.

\section{Conflict of interest}

We declare that we have no conflict of interest.

\section{References}

Abdullah, M.; Eryani, Y. A. and Prakash, R. N. (2007). Antidiabetic activity of stem extracts of Tinospora cordifolia on streptozotocin induced diabetic Wistar rat. Biosciences, Biotechnology Research Asia, 4(2):603-608

Aebi, H.; Sonja, R.; Bernhard, S. and Frantisek, S. (1974). Heterogeneity of erythrocyte catalase $\mathrm{I} 1$, isolation and characterization of normal and variant erythrocyte catalase and their subunits. European Journal of Biochemistry, 48(1):137-145.
Al-Habori, M. and Raman, A. (1998). Antidiabetic and Hypocholesterolaemic effects of Fenugreek. Phytotherapy Research, 12(1):233242 .

Alireza, N.; Mohammad, B.; Mohsen, S.; Ali, F. and Azim, A. (2009). Attenuation of oxidative stress in streptozotocin-induced diabetic rats by Eucalyptus globules. Indian Journal of Clinical Biochemistry, 24(4): 419-425.

Andulla, B. and Varadacharyulu, N. C. H. (2003). Antioxidant role of mulberry leaves in streptozotocin-diabetic rats. Clinical Chemistry Acta, 33(8):3-10.

Arkkila, P. E. T.; Koskinen, P. J.; Kantola, I. M.; Ronnemaa, T.; Seppanen, E. and Viikari, J. S. (2001). Diabetic complications are associated with liver enzyme activities in people with type 1 diabetes. Diabetes Research in Clinical Practice, 52(2):113-118.

Atalay, M. and Laaksonen, D. E. (2002). Diabetes, oxidative stress and physical exercise. Journal of Sports Science and Medicine, 24(1): $1-14$.

Aydemir, T.; Ozturk, R. and Bozkaya, A. (2000). Effects of antioxidant vitamins $\mathrm{A}, \mathrm{C}, \mathrm{E}$ and trace elements $\mathrm{Cu}$, Se on CuZnSOD, GSHPx, CAT and LPO levels in chicken erythrocytes. Cell Biochemistry, 18(6): 109-115.

Aziza, A. M. E.; Magda, M. E.; Moshira, M. E. S.; Hannen, H. M. O. and Doaa, S. I. (2013). Effect of Gymnema sylvestre R. Br. leaves extract on certain physiological parameters of diabetic rats. Journal of King Saud University of Sciences, 25(3):135-141.

Bopama, K. N.; Kanna, J.; Sushma, G.; Balaraman, R. and Rathod, S. P. (1997). Antidiabetic and antihyperlipidemic effects of neem seed kernel powder on alloxan diabetic rabbits. Indian Journal of Pharmacology, 29(2): 162-167.

Bradford, M. M. (1976). A rapid and sensitive method for the quantitation of microgram quantities of protein utilizing the principle of protein-dye binding. Analytical Biochemistry, 72(1):248-254.

Chaturvedi, P. (2005). Role of Momordica charantia in maintaining the normal levels of lipids and glucose in diabetic rats fed a high-fat and low-carbohydrate diet. British Journal of Biomedical Science, 62(3): $124-126$.

Chetan, P. K.; Subhash, L. B.; Arvindkumar, E. G.; Mohan, V. and Prasad, A. T. (2012). Antidiabetic activity of Trigonella foenum-graecum L. seeds extract (IND01) in neonatal streptozotocin-induced (nSTZ) rats. Diabetologia Croatica, 41(1):38-42.

Concepcion, N. M.; Pilar, M. M.; Martin, A.; Jimenez, J. and Pilar, U. M. (1993). Free radical scavenger and antihepatotoxic activity of Rosmarinus tomentosus. Plant Medicine, 59(4):312-314.

Coskun, O.; Kanter, M.; Korkmaz, A. and Oter, S. (2005). Quercetin, a flavonoid antioxidant, prevents and protects streptozotocin-induced oxidative stress and $\beta$-cell damage in rat pancreas. Pharmacology Research, 51(2):117-123.

Creager, M. A. and Luscher, T. F. (2003). Diabetes and vascular disease: pathophysiology, clinical consequences, and medical therapy partI. Circulation, 108(12):1527-1532.

Deepak, A.; Anshu, S. and Garima, S. (2006). Gymnema sylvestre - Boosts your insulin. Drug Information Journal, 34(2):801-808.

Ellman, G. (1959). Tissue sulfhydryl groups. Archives of Biochemistry and Biophysiology, 82(1):70-77.

Eyo, J. E.; Ozougwu, J. C. and Echi, P. C. (2011). Hypoglycaemic effects of Allium cepa, Allium sativum and Zingiber officinale aqueous extracts on alloxan-induced diabetic. Rattus novergicus. Medical Journal of Islamic World Academy of Sciences, 19(3):121-126.

Frances, M. A. and Patrik, R. (2012). Diabetes mellitus and the $\beta$-Cell: The Last Ten Years. Cell, 148(3):1160-1171. 
Ghorbani, A. (2013). Best herbs for managing diabetes: A review of clinical studies. Brazilian Journal of Pharmaceutical Sciences, 49(3):413422 .

Grijesh, K. M.; Pankaj, K. M. and Veeru, P. (2009). Antidiabetic and hypolipidemic activity of Gymnema sylvestre in alloxan induced diabetic rats. Global Journal of Biotechnology and Biochemistry, 4(1):37-42.

Gul, M. Z.; Chandrasekaran, S.; Bhat, M.Y; Maurya, Y; Qureshi, I.A. and Ghazi, I.A. (2016). Antioxidant and enzyme inhibitory activities of Cissampelos pareira L. leaf extracts. Ann. Phytomed., 5(1):9198.

Gupta, R. and Sharma, V. (2011). Ameliorative effects of Tinospora cordifolia root extract on histopathological and biochemical changes induced by aflatoxin b (1) in mice kidney. Toxicology International, 18(1):94-98.

Gupta, S.; Sharma, S. B.; Bansal, S. K. and Prabhu, K. M. (2009). Antihyperglycemic and hypolipidemic activity of aqueous extract of Cassia auriculata L. leaves in experimental diabetes. Journal of Ethnopharmacology, 123(2):499-503.

Hepcy, K. D.; Dinakar, A. and Senthil, K. N. (2012). Antidiabetic activity of ethanolic extracts of Alangium salvifolium and Pavonia zeylanica in streptozotocin induced diabetic rats. International Journal of Pharmacy and Pharmaceutical Sciences, 4(1):337-339.

Ikechukwu, O. J. and Ifeanyi, O. S. (2016). The antidiabetic effects of the bioactive flavonoid (Kaempferol-3-O- $\beta-\mathrm{D}-6\{\mathrm{P}-$ Coumaroyl $\}$ Glucopyranoside) isolated from Allium cepa. Recent Patents on Antiinfective Drug Discovery, 11(1):44-52.

Jha, P.; Momin, A.R.; Kumar, D and Ali, A. (2018). Reversal of glycoxidative damage of DNA and protein by antioxidants. Ann. Phytomed., 7(1):101-105.

Khedekar, S. B.; Ravishankar, B. and Prajapati, P. K. (2015). Antidiabetic activity of dried extract of Tionspora cordifolia (Guduchighana) and honey in streptozotocin induced diabetic rats. International Journal of Green Pharmacy, 9(4):122-126.

Kohen, R. and Nyska, A. (2002). Oxidation of biological systems: Oxidative stress phenomena, antioxidants, redox reactions and methods for their quantification. Toxicological Pathology, 30(6):620-650.

Kokar, R. and Mantham, S. V. (1998). Increased oxidative stress in rat live and pancreas during progression of streptozotosin induced diabetes. Journal of Clinical Science, 8(3):623-632.

Kotadiya Chintu, R.; Patel Urvesh, D.; Modi, C. M.; Patel, H. B.; Kalariya,V.A and Chauhan, V. B. (2017a). Effect of Opuntia elatior fruit juice and quercetin administration on glucose level, lipid profile, hyperalgesic response and spontaneous motor activity in diabetic rats. The Pharma Innovation Journal, 6(8):150-155.

Kotadiya Chintu, R.; Patel Urvesh, D.; Chauhan, V.B.; Patel, H. B.; Modi, C. M.; Bhatt, P.R.; Pandya, K.B. and Shah, T.M. (2017b). In vitro antioxidant and antidiabetic activity of hydroalcoholic extract of Opuntia elatior fruit as well as quercetin. International Journal of Science, Environment and Technology, 6(2):1028-1035.

Kotadiya Chintu, R.; Patel Urvesh, D.; Patel Harshad, B.; Modi Chirag, M. and Fefar Dhaval, T. (2018). Evaluation of effects of Opuntia elatior Mill. fruit juice and quercetin on biochemical parameters and histopathological changes in diabetic rats. Indian Journal of Traditional Knowledge, 17(3):576-583.

Kumar, A. R.; Ilavarasan, T.; Jayachandran, M.; Deecaraman, P.; Aravindan, N.; Padmanabhan. and Krishan, M. R. (2008). Antidiabetic activity of Syzygium cumini and its isolated compound against streptozotocin induced diabetic rats. Journal of Medicinal Plants Research, 2(9): 246-249.
Kumar, G. P. S.; Arulselvan, P.; Kumar, D. S. and Subramanian, S. P. (2006). Antidiabetic activity of fruits of Terminalia chebula on streptozotocin induced diabetic rats. Journal of Health Science, 52(3):283-291.

Kumari, K. and Augusti, K. T. (2002). Antidiabetic and antioxidant effects of S-methyl cysteine sulphoxide isolated from onions (Allium cepa Linn.) as compared to standard drugs in Streptozotocin diabetic rats. Indian Journal of Experimental Biology, 40(3):10051009.

Luna, L. G. (1968). Routine staining procedures. Hematoxylin and eosin stains. Manual histologic staining methods of the Armed Forces Institute of Pathology. (McGraw-Hill, New York), $3^{\text {rd }}$ edition, pp:32-39.

Manoharachary, C. and Nagaraju, D. (2016). Medicinal plants for human health and welfare. Ann. Phytomed., 5(1):24-34.

Marklund, S. and Marklund, G. (1974). Involvement of the superoxide anion radical in the autooxidation of pyrogallol and a convenient assay for superoxide dismutase. European Journal of Biochemistry, 47(1): $469-474$.

Muraki, E.; Hayashi, Y. and Chiba, H. (2011). Dose-dependent effects, safety and tolerability of fenugreek in diet-induced metabolic disorders in rat. Lipids in Health and Disease, 10(3):240-246.

Nayak, A and Subrata De (2013). Antidiabetic potential medicinal plants. Bio.Med.Rx., 1(1):32-46.

Ohaeri, O. C. (2001). Effect of garlic oil on the levels of various enzymes in the serum and tissue of streptozotocin diabetic rats. Bioscience Report, 21(1):19-24.

Ozougwu J. (2011). Antidiabetic effects of Allium cepa (onions) aqueous extracts on alloxan-induced diabetic Rattus novergicus. Journal of Medicinal Plants Research, 5(7):1134-1139.

Patel, R.; Shervington, A.; Pariente, J. A.; Martinez-Burgos, M. A.; Salido, G. M. and Adeghate, E. (2006). Mechanism of exocrine pancreatic insufficiency in streptozotocin induced type-1 diabetes mellitus. Annals of the New York Academy of Sciences, 10(4):71-88.

Perumal, V.; Khoo, W. C.; Abdul-Hamid, A.; Ismail, A.; Saari, K.; Murugesu, S.; Abas, F.; Ismail, I. S.; Lajis, N. H.; Mushtaq, M. Y. and Khatib, A. (2015). Evaluation of antidiabetic properties of Momordica charantia in streptozotocin induced diabetic rats using metabolomics approach. International Food Research Journal, 22(3):1298-1306.

Punithavathi, V. R.; Anuthama, R. and Prince, P. S. (2008). Combined treatment with naringin and vitamin $\mathrm{C}$ ameliorates streptozotocin-induced diabetes in male Wister rats. Journal of Applied Toxicology, 28(6): 806-813.

Rajeshwari, C.U., Shobha, R.I. and Andallu, B. (2013). Oxidative stress and antioxidant effects of herbs and spices in diabetes. Ann. Phytomed., 2(2):13-27.

Rajesh, K. S.; Manjusha, K. B.; Ipseeta, R. M. and Deshmukh, Y. A. (2015). Antidiabetic activity of Gymnema sylvestre leaves extract on streptozotocin induced experimental diabetic rats. Indo American Journal of Pharmaceutical Research, 5(5):163-165.

Raman, A. and Lau, C. (1996). Antidiabetic properties and phytochemistry of Momordica charantia L. (Cucurbitaceae). Phytomedicine, 2(4): 349-662.

Rao, G. S. and Sinsheimer, J. E. (1971). Constituents from Gymnema sylvestre leaves: Isolation, chemistry and derivatives of gymnemagenin and gymnestrogenin. Journal of Pharmaceutical Sciences, 60(2):190-193.

Renuka, C.; Ramesh, N. and Saravanan, K. (2009). Evaluation of the antidiabetic effect of Trigonella foenum-graecum seed powder 
on alloxan induced diabetic albino rats. International Journal of Pharm. Tech. Research, 1(4):1580-1584.

Sharma, B.; Viswanath, G.; Salunke, R. and Roy, P. (2008). Effects of flavonoid rich extract from seeds of Eugenia jambolana L. on carbohydrate and lipid metabolism in diabetic mice. Food Chemistry, 110(3): 697-705.

Shaul,A. R.; Bhatt, P. R.; Modi C.M.; Chauhan, V.B; Pandya H.B.; Patel Urvesh D. and Patel Harshad B. (2017). In vitro antidiabetic activity of different proportions of various extracts from Glycyrrhiza glabra and Tinospora cordifolia. The Pharma Innovation Journal, 6(3): 37-39.

Singh, S. S.; Pandey, S. C.; Srivastava, S.; Gupta, V. S.; Patro, B. and Ghosh, A. C. (2003). Chemistry and medicinal properties of Tinospora cordifolia (Guduchi). Indian Journal of Pharmacology, 35(4):83-91.

Snedecor, G. W. and Cochran, W. G. (1982). Statistical Methods, $8^{\text {thedition. }}$ Ames:Iowa State.
Stanely, P.; Prince, M. and Menon, V. P. (2000). Hypoglycaemic and other related actions of Tinospora cordifolia roots in alloxan induced diabetic rats. Journal of Ethnopharmacology, 70(1):9-15.

Sujin, M. R.; Subin, M. R.; Mahesh, R.; Vinolyia, R. and Mary, J. (2008). Antidiabetic effect of Gymnema sylvestre (Asclepiadaceae) powder in the stomach of rats. Ethnobotanical Leaflets, 12(1):1158-1167.

Tayyab, F. and Lal, S.S. (2016). Comparative study on supplementation effect of Momordica charantia Linn. and Emblica officinalis Gaertn. on lipid profile of type II diabetic patients in Allahabad, Uttar Pradesh, India. Ann. Phytomed., 5(1):40-42.

Wright, E.; Scism-Bacon, Jr, J.L. and Glass, L.C. (2006). Oxidative stress in type 2 diabetes: The role of fasting and postprandial glycaemia. International Journal of Clinical Practice, 60(3):308-314.

Xue, W.; Lei, J.; Li, X. and Zhang, R. (2011). Trigonella foenum-graecum seed extract protects kidney function and morphology in diabetic rats via its antioxidant activity. Nutrition Research, 31(4):555562 . 